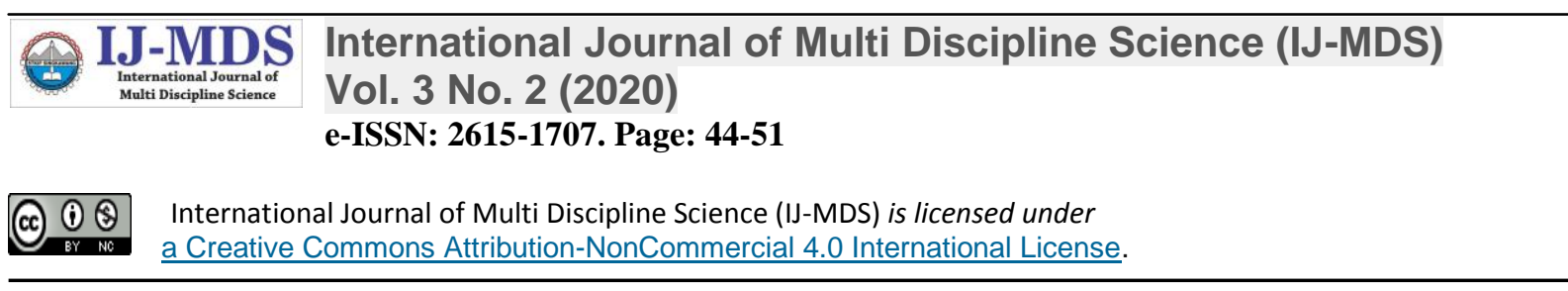

\title{
The Effectiveness of Humic Acid and Trichoderma sp. for Planting Media with Oil Palm Empty Bunches in Pakcoy (Brassica rapa L.)
}

\author{
Aline Sisi Handini ${ }^{1, *)}$, Ratih Rahhutami ${ }^{2}$, Dwi Astutik ${ }^{3}$ \\ Citra Widya Edukasi Palm Oil Polytechnic, Indonesia \\ alinesisihandini@cwe.ac.id ${ }^{1}$, rahhutamiratih@gmail.com², dwias7874@gmail.com ${ }^{3}$ \\ ${ }^{*}$ Corresponding author
}

Keywords:

Humic Acid, Trichoderma sp.,

Pakcoy, EFB

\begin{abstract}
Pakcoy is a vegetable commodity that has high economic value. This study aims to determine the effect of humic acid and Trichoderma sp. by utilizing empty fruit bunch $(E F B)$ waste as a growing medium for Pakcoy growth. The research method used was a two-factor randomized block design. The first factor is humic acid (AH) with three levels: $A H 1=1 \mathrm{~g}, A H 2=2 \mathrm{~g}, A H 3=3 \mathrm{~g}$. The second factor is Trichoderma sp. (T) with three levels; T1 $=50 \mathrm{ml}, \mathrm{T} 2=100 \mathrm{ml}, \mathrm{T3}=150 \mathrm{ml}$. In this study it was concluded, the best treatment was found in the application of humic acid with a dose of $1 \mathrm{~g}$ on the parameters of observation of leaf length, leaf width, plant height, wet weight, and plant dry weight. The use of Trichoderma sp. in this study, does not affect all parameters observation. The results of the analysis of the planting medium showed that the $\mathrm{pH}$ was slightly acidic conditions 5.67 - 6.33. The organic matter content contained in the growing media ranged from 1.20 to $2.62 \%$, and the total $N$-total contained in the growing medium ranged from 0.10 to 0.18 . In-plant tissue analysis shows that the $\mathrm{N}$-total found in plant tissue ranges from $4.62-5.23$.
\end{abstract}

\section{INTRODUCTION}

One of the vegetable commodities that have high economic value is Pakcoy (Brassica rapa, L.). Pakcoy is increasingly favored by the public because of the crispy taste and texture and the larger size of the stalks compared to the mustard greens. The area of Pakcoy planting is also increasing, seen from the easy cultivation technique and relatively short harvest life between 35-40 days after seeding (HSS), thus providing adequate benefits. The nutritional content contained in $100 \mathrm{~g}$ of Pakcoy is $2.39 \mathrm{mg}$ protein; fat $0.39 \mathrm{mg}$; carbohydrates $4.09 \mathrm{mg}$; calcium $220 \mathrm{mg}$; phosphorus $38 \mathrm{mg}$; iron $2.9 \mathrm{mg}$ and vitamin C $102 \mathrm{mg}$ (Kam, 1992). Pakcoy plants are generally grown in the lowlands at temperatures of $15-30^{\circ} \mathrm{C}$. Pakcoy growth 
requires air temperatures ranging from $19{ }^{\circ} \mathrm{C}-21{ }^{\circ} \mathrm{C}$, plant growth is influenced by temperature in the process of plant cell division, germination, sprouting, flowering, and leaf elongation (Cahyono, 2003).

Oil palm empty bunches (TKKS) are solid waste produced by palm oil processing factories or industries. EFB has several advantages, namely enriching the nutrients in the soil and being able to improve physical, chemical, and biological properties, besides containing N, P, K, and $\mathrm{Mg}$ elements needed by plants for their growth (Yunindanova, 2009). The use of oil palm empty bunches (EFB) is an alternative planting medium for Pakcoy with nutrients needed by plants and Trichoderma sp. functions as a decomposer in the composting process, as well as a controlling agent for plant disease Trichoderma $s p$. Another advantage that is also owned by Trichoderma $s p$. is easy to apply, cheap, does not contain toxins, environmentally friendly, and does not interfere with other organisms (Ichwan, 2007).

Humus organic compounds are in the form of decomposition products from plants and animals that have experienced weathering (Bangun, 2016; Katkat et al., 2009; Dani, 2018; Maulana, Sarno, \& Nurmiaty, 2014). Humus can be divided into three groups, namely humic acid, fulvic acid, and humic acid. In this study, the use of humic acid is expected to give a positive response to nutrient absorption in the growth of Pakcoy plants. This study aims to determine the best dose of the effect of humic acid and Trichoderma sp. as well as its interaction on Pakcoy growth in the planting medium of EFB.

\section{METHOD}

This research was conducted at the Citra Widya Edukasi Palm Oil Polytechnic Experimental Garden from September to November 2020. The study used a factorial randomized block design, with two factors. The first factor is humic acid (AH) with three levels, namely: $\mathrm{AH} 1=1 \mathrm{~g}, \mathrm{AH} 2=2 \mathrm{~g}, \mathrm{AH} 3=3$ g. The second factor is Trichoderma sp. (T) with three levels: $\mathrm{T} 1=50 \mathrm{ml}, \mathrm{T} 2=100 \mathrm{ml}, \mathrm{T} 3=150 \mathrm{ml}$. The combination of the two factors resulted in 9 treatments. Each treatment was repeated for three replications, and for each replication, there were three samples. So that in total there were 81 experimental units. The follow-up test used in this study was the Duncans Multiple Range Test (DMRT) at the 5\% real level. The observed parameters observed were: number of leaves, leaf length, leaf width, plant height, wet weight, dry weight, and laboratory analysis including planting media analysis: $\mathrm{pH}, \mathrm{C}$-organic, and $\mathrm{N}$-total, as well as plant tissue analysis: N-total. Pakcoy plant maintenance includes watering, applying basic fertilizer at 1 week after transplanting, and applying vegetable pesticides to prevent pests and plant diseases. Pakcoy harvesting is done after the plants are 35 HSS (days after sowing).

\section{RESULTS AND DISCUSSION}

Based on the recapitulation of variance, Table 1 shows that humic acid treatment at 1 WAP showed a significant effect on leaf width and had a very significant effect on leaf length and plant height, and had no significant effect on the number of leaves. At 2 WAP humic acid treatment for all observation parameters had a very significant effect, and at 3 WAP humic acid treatment did not significantly affect all observed parameters.

Treatment of Trichoderma sp. showed that the results had no significant effect on all observed parameters at 1,2, and $3 \mathrm{WAP}$, and there was no interaction between the two factors tested. The parameters of wet weight and dry weight have a very significant and significant effect on humic acid treatment, respectively, while the application of Trichoderma sp. and the interaction also has no significant effect on Pakcoy's growth. 
Table 1

Recapitulation of the Results of Analysis of the Various Effects of Humic Acid and Trichoderma sp. and Their Interaction with the Observed Parameters

\begin{tabular}{clccc}
\hline $\begin{array}{c}\text { WAP (the Week } \\
\text { After Planting) }\end{array}$ & \multicolumn{1}{c}{$\begin{array}{c}\text { Observed } \\
\text { Parameters }\end{array}$} & $\begin{array}{c}\text { Humic Acid } \\
(\mathbf{A H})\end{array}$ & $\begin{array}{c}\text { Trichoderma } \mathbf{s p} . \\
(\mathbf{T})\end{array}$ & $\begin{array}{c}\text { Interactions } \\
\text { (AHxT) }\end{array}$ \\
\hline \multirow{2}{*}{ Number of leaves } & tn & tn & tn \\
& Leaf length & $* *$ & tn & tn \\
& Leaf width & $*$ & tn & tn \\
& Plant height & $* *$ & tn & tn \\
\hline 2 & Number of leaves & $* *$ & tn & tn \\
& Leaf length & $* *$ & tn & tn \\
& Leaf width & $* *$ & tn & tn \\
\hline 3 & Plant height & $* *$ & tn & tn \\
& Number of leaves & tn & tn & tn \\
& Leaf length & tn & tn & tn \\
\hline & Leaf width & tn & tn & tn \\
& Plant height & tn & tn & tn \\
\hline
\end{tabular}

Note: $* *=$ very significant effect at the $1 \%$ level, $*=$ significant effect at the $5 \%$ level, $\mathrm{tn}=\mathrm{no}$ significant effect, $\mathrm{CV}=$ coefficient variation

Table 2

Effect of Humic Acid and Trichoderma sp. on the Number of Leaves on Pakcoy Growth on EFB Growing Media

\begin{tabular}{lccc}
\hline \multirow{2}{*}{ Treatment } & \multicolumn{3}{c}{ Number of Leaves } \\
\cline { 2 - 4 } & 1 WAP & 2 WAP & 3 WAP \\
\hline Humic acid (AH) & & & \\
\hline AH1 $: 1 \mathrm{~g}$ & 3.85 & $6.48 \mathrm{a}$ & 10.29 \\
AH2 $: 3 \mathrm{~g}$ & 3.67 & $6.33 \mathrm{a}$ & 10.18 \\
AH3 $: 5 \mathrm{~g}$ & 3.62 & $5.48 \mathrm{~b}$ & 10.00 \\
\hline Trichoderma sp. $(\mathrm{T})$ & & & \\
\hline T1 $: 50 \mathrm{ml}$ & 3.77 & 6.22 & 110.37 \\
T2 $: 100 \mathrm{ml}$ & 3.74 & 6.11 & 10.37 \\
T3 $: 150 \mathrm{ml}$ & 3.62 & 5.96 & 9.74 \\
\hline Interaction (AHxT) & tn & tn & tn \\
CV $(\%)$ & 12.33 & 11.31 & 17.02 \\
\hline
\end{tabular}

Note: $* *=$ very significant effect at the $1 \%$ level, $*=$ significant effect at the $5 \%$ level, $\mathrm{tn}=$ no significant effect, $\mathrm{CV}=$ coefficient variation

Based on the statistical analysis in Table 2 shows the application of humic acid and Trichoderma sp. at 1 WAP there is no significant effect and there is no interaction between the two of the growth of Pakcoy in the OPEFB growing media. It is suspected that the application of humic acid and Trichoderma sp. At 1 WAP there was no positive response to the number of Pakcoy leaves, due to the transplanting of Pakcoy seedlings. Adaptation is needed by plants from the seeding location to the enlargement location with different types of planting media between seeding and enlargement media, so that the treatment has not shown a significant effect on the number of Pakcoy leaves. The number of leaves at 2 WAP showed a significant difference in humic acid treatment. The highest number of Pakcoy leaves at 2 WAP was found in $\mathrm{AH} 1$ treatment of 6.48 , but not significantly different in $\mathrm{AH} 2$ treatment. 
The lowest number of leaves was shown by AH3 treatment as much as 5.48 and significantly different from AH1 and 2. This indicates that the amount of humic acid required in small amounts for the growth of Pakcoy plants. Following the statement (Ayas and Gulser, 2005) application of humic acid at low concentrations can increase the $\mathrm{N}$ and $\mathrm{P}$ uptake of spinach plants (Ayas and Gulser, 2005). Application of Trichoderma sp. showed that there was no significant difference between all treatments at 1,2, and 3 WAP. Trichoderma sp. the number of Pakcoy leaves was not significantly different, it is presumed that Trichoderma sp. is a biological agent that has a role as a decomposer.

Table 3

Effect of Humic Acid and Trichoderma sp. on the Leaf Length on Pakcoy Growth on EFB Growing Media

\begin{tabular}{|c|c|c|c|}
\hline \multirow{2}{*}{ Treatment } & \multicolumn{3}{|c|}{ Leaf Length (cm) } \\
\hline & 1 WAP & 2 WAP & 3 WAP \\
\hline \multicolumn{4}{|l|}{ Humic acid (AH) } \\
\hline AH1 : $1 \mathrm{~g}$ & $5.43 \mathrm{a}$ & $12.85 \mathrm{a}$ & 18.34 \\
\hline $\mathrm{AH} 2: 3 \mathrm{~g}$ & $5.11 \mathrm{a}$ & $12.80 \mathrm{a}$ & 18.27 \\
\hline $\mathrm{AH} 3: 5 \mathrm{~g}$ & $4.38 \mathrm{~b}$ & $10.37 \mathrm{~b}$ & 17.95 \\
\hline \multicolumn{4}{|c|}{ Trichoderma sp. $(\mathrm{T})$} \\
\hline $\mathrm{T} 1: 50 \mathrm{ml}$ & 5.20 & 12.34 & 18.72 \\
\hline $\mathrm{T} 2: 100 \mathrm{ml}$ & 4.95 & 11.96 & 17.96 \\
\hline $\mathrm{T} 3: 150 \mathrm{ml}$ & 4.78 & 11.72 & 17.88 \\
\hline Interaksi (AHxT) & tn & tn & $\operatorname{tn}$ \\
\hline $\mathrm{CV}(\%)$ & 20.14 & 16.06 & 9.86 \\
\hline
\end{tabular}

Table 3 shows that from the results of statistical analysis, there is a significant difference in humic acid treatment at $1 \mathrm{WAP}$ and $2 \mathrm{WAP}$, and not significantly different at $3 \mathrm{WAP}$. At $1 \mathrm{WAP}, \mathrm{AH} 1$ treatment showed the highest leaf length, namely 5.43, although it was not significantly different from AH2 treatment. The same thing also happened at 2 WAP for the highest leaf length in AH1 treatment but not significantly different from $\mathrm{AH} 2$ treatment. And $\mathrm{AH} 3$ treatment showed the lowest leaf length and was significantly different from AH1 and $\mathrm{AH} 2$ at $1 \mathrm{WAP}$ and 2 WAP. These results indicate that the need for humic acid for Pakcoy plants is needed in low doses. Darmawan (2017) stated that humic acid is useful for stimulating plant growth and development, with an increase in plant cell energy which results in an intensification activity of the ion exchange process which accelerates the growth of the root system and makes the roots longer so that nutrient absorption is faster. Application of Trichoderma sp. showed that there was no significant difference between all treatments at 1, 2, and 3 WAP. Pakcoy leaf length was not significantly different from the application of Trichoderma $s p$. for all treatment doses.

Based on the statistical analysis in Table 4, the application of humic acid at 1 WAP and 2 WAP shows a significant difference, while at 3 WAP there is no significant difference for the three humic acid doses. Application of Trichoderma sp. showed that there was no significant difference between all treatments at 1,2, and 3 WAP. Pakcoy leaf length was not significantly different from the application of Trichoderma sp. for all treatment doses.

Humic acid treatment at 1 WAP and 2 WAP showed the largest leaf width in AH1 treatment, but it was not significantly different from $\mathrm{AH} 2$ treatment. The smallest leaf width was found in $\mathrm{AH} 3$ treatment and was significantly different from AH1. It is known that humic acid has the benefit of stimulating plant growth and development so that the absorption of nutrients by plants is optimal. According to Firda, Mulyani, and Yuniarti (2016), humic acid contains 40-80\% C elements, 2-4\% N elements, $1-2 \% \mathrm{~S}$ elements, and $0-0.3 \% \mathrm{P}$ elements. The amount of element $\mathrm{N}$ which is high enough in humic acid can increase fertility and nutritional adequacy for plants. 
Tabel 4

Effect of Humic Acid and Trichoderma sp. on the Leaf Width on Pakcoy Growth on EFB Growing Media

\begin{tabular}{|c|c|c|c|}
\hline \multirow{2}{*}{ Treatment } & \multicolumn{3}{|c|}{ Leaf Width (cm) } \\
\hline & 1 WAP & 2 WAP & 3 WAP \\
\hline \multicolumn{4}{|l|}{ Humic acid (AH) } \\
\hline $\mathrm{AH} 1: 1 \mathrm{~g}$ & $2.23 \mathrm{a}$ & $4.87 \mathrm{a}$ & 7.42 \\
\hline $\mathrm{AH} 2: 3 \mathrm{~g}$ & $2.13 \mathrm{ab}$ & $4.80 \mathrm{a}$ & 7.05 \\
\hline $\mathrm{AH} 3: 5 \mathrm{~g}$ & $1.94 \mathrm{~b}$ & $3.87 \mathrm{~b}$ & 6.91 \\
\hline \multicolumn{4}{|l|}{ Trichoderma sp. (T) } \\
\hline $\mathrm{T} 1: 50 \mathrm{ml}$ & 2.21 & 4.69 & 7.21 \\
\hline $\mathrm{T} 2: 100 \mathrm{ml}$ & 2.11 & 4.51 & 7.17 \\
\hline $\mathrm{T} 3: 150 \mathrm{ml}$ & 1.98 & 4.32 & 7.01 \\
\hline Interaction $(\mathrm{AHxT})$ & tn & tn & tn \\
\hline $\mathrm{CV}(\%)$ & 18.27 & 16.02 & 12.70 \\
\hline
\end{tabular}

Table 5

Effect of Humic Acid and Trichoderma sp. on the Plant Height on Pakcoy Growth on EFB Growing Media

\begin{tabular}{|c|c|c|c|}
\hline \multirow{2}{*}{ Treatment } & \multicolumn{3}{|c|}{ Plant Height (cm) } \\
\hline & 1 WAP & 2 WAP & 3 WAP \\
\hline \multicolumn{4}{|l|}{ Humic acid (AH) } \\
\hline AH1 $: 1 \mathrm{~g}$ & $6.42 \mathrm{a}$ & $14.32 \mathrm{a}$ & 21.31 \\
\hline $\mathrm{AH} 2: 3 \mathrm{~g}$ & $6.09 \mathrm{a}$ & $14.01 \mathrm{a}$ & 21.17 \\
\hline $\mathrm{AH} 3: 5 \mathrm{~g}$ & $5.23 \mathrm{~b}$ & $11.39 \mathrm{~b}$ & 20.38 \\
\hline \multicolumn{4}{|l|}{ Trichoderma sp. (T) } \\
\hline $\mathrm{T} 1: 50 \mathrm{ml}$ & 6.05 & 13.54 & 21.47 \\
\hline $\mathrm{T} 2: 100 \mathrm{ml}$ & 5.97 & 13.33 & 20.74 \\
\hline $\mathrm{T} 3: 150 \mathrm{ml}$ & 5.72 & 12.86 & 20.65 \\
\hline Interaction (AHxT) & tn & tn & tn \\
\hline $\mathrm{CV}(\%)$ & 18.06 & 13.03 & 8.47 \\
\hline
\end{tabular}

The results of statistical analysis in Table 5 show that the application of humic acid at 1 WAP and 2 WAP shows a significant difference, while at 3 WAP there is no significant difference for the three humic acid doses. Application of Trichoderma sp. showed that there was no significant difference between all treatments at 1,2, and 3 WAP. Pakcoy plant height was not significantly different from the application of Trichoderma sp. for all treatment doses.

Humic acid treatment at $1 \mathrm{WAP}$ and $2 \mathrm{WAP}$ showed the highest plant height in AH1 treatment but not significantly different from $\mathrm{AH} 2$ treatment. The smallest plant height was found in $\mathrm{AH} 3$ treatment and was significantly different from $\mathrm{AH} 1$ and $\mathrm{AH} 2$. It is known that humic acid has the benefit of stimulating plant growth and development at low doses so that the absorption of nutrients by plants is optimal. Humic acid also triggers an increase in energy in plant cells, thereby increasing the activity of plant growth and development (Darmawan, 2017). 
Table 6

Effect of Humic Acid and Trichoderma sp. on the Wet and Dry Weight on Pakcoy Growth on EFB

Growing Media

\begin{tabular}{lcc}
\hline \multicolumn{1}{c}{ Treatment } & Wet Weight (gram) & Dry Weight (gram) \\
\hline Humic acid (AH) & & \\
\hline AH1 $: 1 \mathrm{~g}$ & $24.79 \mathrm{a}$ & $1.34 \mathrm{a}$ \\
$\mathrm{AH} 2: 3 \mathrm{~g}$ & $23.10 \mathrm{a}$ & $1.21 \mathrm{a}$ \\
$\mathrm{AH} 3: 5 \mathrm{~g}$ & $19.10 \mathrm{~b}$ & $1.02 \mathrm{~b}$ \\
\hline Trichoderma sp. $(\mathrm{T})$ & & \\
T1 $: 50 \mathrm{ml}$ & 23.19 & 1.26 \\
$\mathrm{~T} 2: 100 \mathrm{ml}$ & 22.27 & 1.22 \\
$\mathrm{~T} 3: 150 \mathrm{ml}$ & 21.52 & 1.09 \\
\hline Interaksi $(\mathrm{AHxT})$ & th & th \\
KK $(\%)$ & 6.78 & 17.55 \\
\hline Note: $* *$ very significant effect at the $1 \%$ level, $*$ significant effect at the \\
\multicolumn{2}{c}{ 5\% level, tn = no significant effect. CV $=$ coefficient variation }
\end{tabular}

The results of statistical analysis in Table 6, showed that the wet weight and dry weight in the humic acid application were significantly different. The highest wet weight was found in AH1 treatment with the lowest humic acid dose, but it was not significantly different from $\mathrm{AH} 2$ treatment. The lowest wet weight was found in $\mathrm{AH} 3$ treatment and significantly different from $\mathrm{AH} 1$ and $\mathrm{AH} 2$ treatments. This shows that the application of low doses of humic acid gave a positive response to the growth and development of Pakcoy plants which correlated with plant wet weight. Although the wet weight of Pakcoy in this study was classified as low, the consequence and need for regular fertilization were to increase plant growth so that it was correlated with wet weight.

Plant dry weight indicates that AH1 treatment has the highest dry weight, although it is not significantly different from AH2 treatment, and significantly different from AH3 treatment. Suwardi Dewi, and Hermawan (2009) explained that the application of humic acid to the soil was able to increase rice yields by $15 \%$ and maize yields by $10 \%$ at a dose of 10 liters/ha. This is in line with the application of humic acid to increase the yield of Pakcoy plants. Application of Trichoderma sp. in this case, did not show any significant difference from the three doses applied to the Pakcoy plant. It is suspected that Trichoderma sp. plays a role in the decomposition process of EFB organic matter and does not have a direct role in the absorption of nutrients for plant growth and development.

Table 7

Data Analysis of Planting Media and Nutrients in Pakcoy Plants

\begin{tabular}{ccccc}
\hline $\begin{array}{c}\text { Treatment } \\
\text { AH: Humic acid }\end{array}$ & \multicolumn{3}{c}{ Analysis of Planting Media } & $\begin{array}{c}\text { Analysis of } \\
\text { Plant Tissue }\end{array}$ \\
\cline { 2 - 5 } T: Trichoderma sp & pH & C-organic (\%) & N-total (\%) & N-total (\%) \\
\hline AH1T1: $1 \mathrm{~g}+50 \mathrm{ml}$ & 5.67 & 1.20 & 0.13 & 4.94 \\
AH1T2: $1 \mathrm{~g}+100 \mathrm{ml}$ & 5.83 & 1.46 & 0.10 & 5.16 \\
AH1T3: $1 \mathrm{~g}+150 \mathrm{ml}$ & 5.87 & 1.59 & 0.11 & 5.01 \\
AH2T1: $3 \mathrm{~g}+50 \mathrm{ml}$ & 5.99 & 1.91 & 0.15 & 5.10 \\
AH2T2: $3 \mathrm{~g}+100 \mathrm{ml}$ & 5.85 & 1.64 & 0.18 & 4.81 \\
AH2T3: $3 \mathrm{~g}+150 \mathrm{ml}$ & 5.75 & 1.35 & 0.13 & 4.69 \\
AH3T1: $5 \mathrm{~g}+50 \mathrm{ml}$ & 5.68 & 1.92 & 0.13 & 5.17 \\
AH3T2: $5 \mathrm{~g}+100 \mathrm{ml}$ & 5.82 & 2.62 & 0.16 & 5.23 \\
AH3T3: $5 \mathrm{~g}+150 \mathrm{ml}$ & 6.33 & 1.84 & 0.13 & 4.62 \\
\hline
\end{tabular}

Table 7 shows that the analysis of the planting medium was carried out to determine the condition of the planting medium as a place to grow Pakcoy plants. The results of the analysis showed that the $\mathrm{pH}$ of the planting medium ranged from $5.67-6.33$. The $\mathrm{pH}$ conditions are rather acidic, and soil $\mathrm{pH}$ 
determines the ease with which nutrients can be absorbed by plants (Yuniarti et al., 2017). Generally, nutrients are easily absorbed in a neutral $\mathrm{pH}(6-7)$, because at that $\mathrm{pH}$ some nutrients dissolve easily in water. The $\mathrm{C}$-organic and $\mathrm{N}$-total content of the analyzed soil was classified as low, so it was necessary to add fertilizer. The C-organic content contained in the growing medium ranged from 1.20 to $2.62 \%$ which was classified as low, and the total $\mathrm{N}$-amount contained in the growing medium was also low, ranging from 0.10 to 0.18 . This amount is quite low for the need for nitrogen nutrients for plants, especially Pakcoy, so it is better if fertilizer is added to support plant growth. In-plant tissue analysis shows that the total amount of $\mathrm{N}$ found in plant tissue ranges from $4.62-5.23$.

\section{CONCLUSIONS}

In this study, it was concluded that the best treatment was found in the application of humic acid with a dose of $1 \mathrm{~g}$ on the parameters of the observation of leaf length, leaf width, plant height, wet weight, and plant dry weight. The use of Trichoderma sp. in this study, did not have a real effect on all benchmarks. The results of statistical analysis showed that there was no interaction between the two factors. The results of the analysis of the planting medium showed a slightly acidic $\mathrm{pH}$ ranging from $5.67-6.33$, organic matter $1.20-2.62 \%$, while the amount of $\mathrm{N}$-total was quite low ranging from 0.10 - 0.18. The result of plant tissue analysis showed that the amount of $\mathrm{N}$-total was quite high, ranging from $4.62-5.23$.

\section{REFERENCES}

Ayas, H. and F. Gulser. (2005). The Effect of Sulfur and Humic acid on yield components and macronutrient contents of spinach. J. Biological Sci, 5(6), 801-804.

Bangun, R.A. (2016). Pengaruh Asam Humat dan Pupuk NPK terhadap pH, C-organik, Ntotal, C/N, KTK dan Hasil Pakcoy pada Inceptisols Jatinangor. Skripsi. Universitas Padjadjaran.

Dani, U. (2018). Pengaruh Kombinasi Asam Humat, Jarak Tanam, dan Jumlah Bibit per Lubang Tanam Terhadap Pertumbuhan dan Hasil Tanaman Padi (Oryza satiiva L. 'Pandan Puteri'). Jurnal Ilmu Pertanian dan Peternakan, 6(1), 8-9.

Darmawan. (2017). Manfaat Asam Humus (Humic Acid) Bagi Tanaman Padi di Lahan Sawah Sub Optimal Pasang Surut. Buletin Hasil Kajian, 7(6).

Firda, O., Mulyani., \& Yuniarti, A. (2016). Pembentukan, Karakteristik serta Manfaat Asam Humat Terhadap Adsorbsi Logam Berat (Review). Jurnal Soilrens, 14(2), 9-13.

Ichwan, B. (2007). Pengaruh Dosis Tricho-kompos terhadap Pertumbuhan dan Hasil Tanaman Cabe Merah (Capsicum annuum L.). Fakultas Pertanian Universitas Jambi Kampus Pinang Masak, Mendalo Dara. Jambi.

Kam, N.O. (1992). Daftar Analisis Bahan Makanan. Fakultas Kedokteran UniversitasIndonesia. Jakarta.

Katkat, A.V., Çelik, H., Turan, M.A., \& Asýk, B.B. (2009). Effects of Soil and Foliar Applications of Humic Substances on Dry Weight and Mineral Nutrients Uptake of Wheat under Calcareous Soil Conditions. Aust. J. Basic and Appl. Sci., 3(2), 12661273.

Maulana, D., Sarno., \& Nurmiaty, Y. (2014). Pengaruh Aplikasi Asam Humat dan Pemupukan Fosfor terhadap Serapan Unsur Hara P dan K Tanaman Tomat (Lycopersicum Esculentum). J. Agrotek Tropika, 2(2), 302-305.

Suwardi, E.M., Dewi., \& Hermawan, B.A. (2009). Aplikasi Zeolit sebagai Karier Asam Humat untuk Peningkatan Produksi Tanaman Pangan. Jurnal Zeolit Indonesia, 8(1), 44-51. 
- IJ-MDS International Journal of Multi Discipline Science (IJ-MDS)

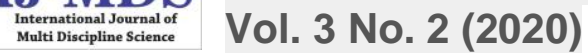

e-ISSN: 2615-1707. Page: 44-51

Yunindanova, M B. (2009). Tingkat Kematangan Kompos Tandan Kosong Kelapa Sawit dan Penggunaan Berbagai Jenis Mulsa terhadap Pertumbuhan Dan Produksi Tanaman Tomat (Lycopersicon esculentum). Skripsi. Bogor: Institut Pertanian Bogor. 